\title{
Qualitative characteristics of meat from cull cows of different genotypes and age class slaughter under different finishing systems: a meta-analytic approach
}

\author{
RANGEL F. PACHECO, ANDREI R. MAYER, MARCOS A.B. VAZ, LUCIANA PÖTTER, \\ JONATAS CATTELAM, ÁLISSON M. CALLEGARO, LUIZ ANGELO D. PIZZUTI, \\ IVAN L. BRONDANI, DARI C. ALVES FILHO and PAULO S. PACHECO \\ Departamento de Zootecnia, Universidade Federal de Santa Maria, \\ Avenida Roraima, 1000, Camobi, 97105-900 Santa Maria, RS, Brasil
}

Manuscript received on July 4, 2014; accepted for publication on October 14, 2014

\begin{abstract}
The aim of this study was to evaluate, by meta-analysis, the quality of the meat of the cows according to genotype, termination system and age class slaughter. During an online research were identified 15 articles with information related to meat quality of slaughtered cows. The data were grouped according of the genotype of cows being: zebu or continental defined, crossed zebu x british or zebu x continental; according to termination system: feedlot or grassland; according to age of slaughter, where: up to 4 years old (young), 4-8 years old (adult) or more than 8 years old (old). The meat of the continental crossbred cows was softer than the other genotypes, both panel of evaluators and by Shear. The meat of cows finished in feedlot showed higher marbling degree in relation to meat of females finished on grassland. The reduction of the slaughter age of cows improved the meat color. The cow's genotype affects the organoleptic aspects of meat while the finished system and slaughter age affects the sensory aspects of meat.
\end{abstract}

Key words: confinement, female cattle, softness, crossbred, shear, zebu.

\section{INTRODUCTION}

Because of the wide territorial extension and changes in climatic conditions and part of Brazil is possible to identify changes in production systems and, consequently, the type of animals for slaughter. Especially in the case of slaughter of cows due to range in age at slaughter and different genotypes that make up the herd in the country, impacting considerably on the quality of the meat of animals in this category.

Although was confirmed the negative effect of zebu genotype on meat quality in cattle, especially tenderness (Crouse et al. 1989, Veiseth et al. 2004,

Correspondence to: Rangel Fernandes Pacheco

E-mail: rangelzootec@hotmail.com
Lage et al. 2012, Tizioto et al. 2014), the female bovines of zebu that have a better adaptation to the conditions of environment imposed by the tropical climate of Brazil, which makes it essential to adopt this genotype in herds in the country. However, the increased participation of cattle breeds of European origin (Bos taurus taurus) both continental and British, in crosses with zebu, which has occurred most markedly in the last decade, may contribute to improvements in the quality of beef cows. However, information about the quality of beef and females derived from crosses between zebu breeds with British and continental are scarce, mainly due to practical difficulties of bringing, together in 
a single study, cows disposal from these crosses, which makes the approach meta-this fundamental analytical case.

Negatives attributes are constantly directed to carcass characteristics and beef cows (Stelzleni et al. 2007), however, researches have demonstrated that improvement in organoleptic and sensory aspects of meat can be obtained with better quality diets during the slaughter of cows termination (Vastergaard et al. 2000, Weber et al. 2013). Vaz et al. (2007) and Menezes et al. (2010) have observed that the use of confinement in the termination phase allowed improvements in tenderness of meat from steers in relation to cattle finished on pasture, but the other organoleptic attributes the results were conflicting, that evidence the effect of production systems on variations in meat quality of steers. In other hand, there are few researches about the effects of termination system in cull cows. It turns difficult a clear comprehension of this aspect in the quality of the meat of this category.

The variation of age at slaughter of cows is among the features of major importance when it reports the quality of the meat of cows. The links of collagen in the muscle, which is constant in all animals at different ages, they become more resistant and stable with advancing age, making it more rigid and chewy meat, and this characteristic have indicated as one of the main responsible for the variation the tenderness of the meat that category (Jurie et al. 2006). However, in certain situations the effects of age and reflections that may have on the meat is no significant change point qualitative aspects capable of being perceivable by the consumer (Galli et al. 2008), which makes it highly relevant studies aimed variations in meat quality attributes and their relationships with the age of slaughter of cows.

The objective of this study was to evaluate the effects of genotype, the termination system and age class of beef from meta-analytic approach, on the qualitative and organoleptic aspects of meat.

\section{MATERIALS AND METHODS}

The research was performed at the Laboratory of Beef Cattle, Department of Animal Science, UFSM-RS. This rummage is based in 35 articles of researches have done in Brazil, published from 2000 to March 2013 in Brazilian journals accessed through the Internet by search platforms SciELO and Capes. This interval was due to the reachability search platforms used during research. The aim of the search was to evaluate articles that have studied the characteristics of beef cull cows, for that, they were located from the combination of the following keywords: carcass, meat, female cattle, heifers and cows.

In the selection of articles was done screening to avoid double data collected from the same research. After this screening, 15 articles were selected, of which were excluded variables that contemplated the premise of having used the same methodology for the estimates of the variables: marbling, texture, color, tenderness, shear force (Shear), softness and palatability.

The articles selected for the database, as well as the number of animals used in each and extracted observations of articles, are presented in Tables I and II

Regarding the type of termination system prevalent in the studies considered to make the database; they were finished in natural pastures, oats and ryegrass pastures or confinement. For the researches that have analyzed cows terminated on pasture, in $70 \%$ of supplementation was used, it being on average $0.5 \%$ of BW. For feedlot diets the stover was composed mostly of corn silage, sorghum silage or sugar cane; the most concentrated fractions ingredients used were corn, soybean meal and common salt, and is the roughage: concentrate on average 50:50.

The methodology used for the determination of sensory and organoleptic characteristics of meat have used the methodology proposed by Muller (1987) and cited by Metz et al. (2009). The variables used to compose the database have been selected in the sections of Materials and Methods and Results 
TABLE I

Articles that were the basis of data from meta-analysis and number of animals (n) used in each study and extracted observations of each item per variable.

\begin{tabular}{lcccccccc}
\hline \multirow{2}{*}{\multicolumn{1}{c}{ Articles }} & \multirow{2}{*}{$\mathbf{n}$} & \multicolumn{1}{c}{ Variables } \\
\cline { 2 - 9 } & & 1 & 2 & 3 & 4 & 5 & 6 & 7 \\
\hline Cattelam et al. (2009) & 12 & 2 & 2 & 2 & 2 & 2 & 2 & 2 \\
Fernandes et al. (2008) & 10 & - & - & - & 1 & - & - & - \\
Kuss et al. (2005) & 8 & 3 & 3 & 3 & 3 & 3 & 3 & 3 \\
Kuss et al. (2006) & 12 & 2 & 2 & 2 & 2 & 2 & 2 & 2 \\
Leão et al. (2013) & 12 & 4 & 4 & 4 & 4 & - & - & - \\
Marques et al. (2006) & 19 & 3 & 3 & 3 & - & 3 & 3 & 3 \\
Menezes et al. (2009) & 30 & 3 & 3 & 3 & 3 & 3 & 3 & 3 \\
Moura et al. (2013) & 20 & 2 & 2 & 2 & - & - & - & - \\
Osmari et al. (2008) & 28 & 2 & 2 & 2 & 2 & 2 & 2 & 2 \\
Restle et al. (2001a)* & 25 & 2 & 2 & 2 & 2 & 2 & 2 & 2 \\
Restle et al. (2001b) & 30 & 4 & 4 & 4 & - & - & - & - \\
Restle et al. (2003)* & 25 & 3 & 3 & 3 & 3 & 3 & 3 & 3 \\
Vaz et al. (2002a) & 40 & 4 & 4 & 4 & 4 & 4 & 4 & 4 \\
Vaz et al. (2002b) & 6 & 1 & 1 & 1 & 1 & 1 & 1 & 1 \\
Vaz et al. (2010) & 12 & 1 & 1 & 1 & 1 & 1 & 1 & 1 \\
Total & 264 & 36 & 37 & 36 & 28 & 36 & 26 & 26 \\
\hline
\end{tabular}

$\mathbf{1}=$ coloring; $\mathbf{2}=$ texture; $\mathbf{3}=$ marbling; $\mathbf{4}=$ tenderness (shear); $\mathbf{5}=$ tenderness (panel); $\mathbf{6}=$ succulence; $\mathbf{7}=$ palatability.

* Same study, however, evaluated differently.

TABLE II

Number of animal studies and observations drawn from the articles for each effect assessed.

\begin{tabular}{ccccccccc}
\hline \multirow{2}{*}{ Articles } & \multirow{2}{*}{$\mathbf{n}$} & \multicolumn{7}{c}{ Variables } \\
\cline { 3 - 9 } & 1 & 2 & 3 & 4 & 5 & 6 & 7 \\
\hline Genotype & 237 & 35 & 36 & 35 & 24 & 30 & 28 & 30 \\
System & 264 & 40 & 40 & 40 & 32 & 30 & 30 & 31 \\
Age class & 249 & 36 & 36 & 36 & 32 & 30 & 29 & 30 \\
\hline
\end{tabular}

of each article and tabulated in Excel spreadsheet, version 2013 Program, composing the database. Data were grouped according to the following genotype: zebu, continental, british or mixed with zebu crossbred with continental; in relation to the production system, which were: confinement or pasture and depending on the age class of cows to slaughter: young (up to 4 years old), adult (from 4 to 8 years old) and old (over 8 years of age).

The effects of the leading cause of variation were evaluated (genotype termination system and age class) as well the interactions between them.
In the absence of interactions between the main effects, these were removed from the model.

To choose the mathematical model, the number of repetitions of each medium extracted from articles that comprised the database was used as a covariate. The inclusion of the number of repetitions in the model was given on the basis of differences in experimental designs and number of repetitions of the researches that made up the database, due to the need to consider the effects of the studies as random effects rather than fixed (St-Pierre 2007).

The mathematical model used for the analysis of variance was:

$$
y i j k l=\mu+n+\alpha i+\beta j+\tau k+\varepsilon i j k l
$$

yijkl variable is observed in the n-th repetition with i-th level of genetic dominance factor with the $\mathrm{j}$-th level of the system termination factor with the k-th level of the age class factor in the 1-th iteration; $\mu$ is the overall mean; $\mathrm{n}$ is the covariate number of repetitions of each medium; ai is the effect of the ith level of the predominant genetic factor; $\beta \mathrm{j}$ is the effect of the $\mathrm{jth}$ level of the factor system termination; $\tau \mathrm{k}$ is the effect of the $\mathrm{k}$-th level of factor age class; eijkl is the error associated with the observed variable, being $\operatorname{cijkl} \sim \mathrm{N}(0, \sigma 2)$ independent and identically distributed.

The next part have involved statistical analyzes, proceeding to test for normality by Shapiro-Wilk (5\%), when necessary variables were submitted, it is: the variable texture ((x ** 2)). Subsequently, the data were submitted to variance analysis, F-test, correlation and analysis of contrasts, all at 5\% probability. When differences were found for the effect of genotype, age or termination system the averages were compared by Tukey test at $5 \%$ probability.

\section{RESULTS AND DISCUSSION}

There was not interaction between study effects (genotype, age and termination system) and thus removed from the mathematical model. The 
genotypes influence the qualitative and organoleptic characteristics of meat from cows (Table III and IV). The meat of the British crossbred demonstrated coloring classified as "red" (4.28 points) which are distinct from continental crossbred (3.30 points) and zebu set (3.12 points), which were "slightly dark red" while the meat of the continental defined showed "slightly dark red" color with a strong tendency to "red" (3.79 points), doing the latter similar to genotypes with some degree of zebu blood. The reason for these differences is related to a less reactive temperament of british and continental animals, which in turn makes these have a lower pre-slaughter stress and therefore a decrease burning of glycogen and $\mathrm{pH}$ drop the meat, producing meat with better attributes. According to Field (1971) the concentration of muscle glycogen in animals pre-slaughter phase is considered one of the marks that demonstrates greater effect on the change in the color of meat. Muller (1987) highlights that meat with darker color is deprecated at the retail level because the consumer associates it with older or poor maintenance animals.

TABLE III

Qualitative characteristics of meat from cull cows of different genetic predominance.

\begin{tabular}{cccc}
\hline Genetic Group & Coloring $^{\mathbf{1}}$ & Texture $^{\mathbf{2}}$ & Marbling $^{\mathbf{3}}$ \\
\hline Zebu & $3.11 \pm 0.37^{\mathrm{b}}$ & $2.94 \pm 0.83$ & $8.36 \pm 1.18$ \\
Continental & $3.77 \pm 0.14^{\mathrm{ab}}$ & $3.64 \pm 0.27$ & $6.26 \pm 1.14$ \\
Zebu x British & $4.27 \pm 0.23^{\mathrm{a}}$ & $3.43 \pm 0.27$ & $4.24 \pm 1.14$ \\
Zebu x Continental & $3.28 \pm 0.12^{\mathrm{b}}$ & $3.31 \pm 0.23$ & $5.41 \pm 0.52$ \\
Average & 3.59 & 3.34 & 5.98 \\
Probability & 0.0063 & 0.7969 & 0.2174 \\
Difference & & & -1.68 \\
Definided $v$ Crossbred & 0.31 & 0.32 & 2.22 \\
Cros. + Zeb. $v s$ Cont. & -0.36 & -0.36 & -5.58 \\
Cros. + Cont. $v s$ Zeb. & 0.98 & 1.00 & \\
\hline
\end{tabular}

Cros. $=$ Crossbred; Zeb. $=$ Zebu; Cont.$=$ Continental .

${ }^{1}$ Coloring: $1=$ dark; $2=$ dark red; $3=$ slighty dark red ; $4=$ red; $5=$ bright red.

${ }^{2}$ Texture: $1=$ very chewy; $2=$ chewy; $3=$ slighty chewy; $4=$ thin; $5=$ very thin.

${ }^{3}$ Marbling: $1-3=$ traits; $4-6=$ light; $7-9=$ small; $10-12=$ medium; $13-15=$ moderate; $16-18=$ abundant.

The meat of bovine females showed similar textures between genotypes. This variable is assessed in a subjective way, by granulating surface when the muscle is cut only correlated with marbling score $(r=-0.35, P=0.0264)$. Some studies associate zebu genotypes coarser texture of meat from cattle. However, even though the meat of zebu cows set (2.94 points) have demonstrated "chewy" texture with a strong tendency to "slightly rough", there was a big difference from the texture of the meat of the set (3.77 points) and crossbreed (3.28 points) Continental, ranked between "slightly coarse" and "fine", and was not different of british crossbred (4.27 points), "thin".
Although the values for marbling of the meat of zebu cows was classified as "small" (8.36 points), it was similar to the meat of cows defined continental (6.26 points), Continental crossbred (5.41 points) and to that of British crossbred (4.24 points), even those demonstrating marbling classified as "traits".

When comparisons were made between the crossbred cows or defined, by contrast analysis, it was observed that the crossing did not change significantly the qualitative property of the meat, these traits are able to get noticed by the consumer when he chooses the product (color, texture and marbling). This trend also extended to comparisons between crossbred against defined, continental or zebu. Results of researches 
with steers demonstrate that the effect of heterosis arising from cross between Narolais and Nellore promotes improvements in quantitative, qualitative and physical carcass composition (Menezes et al. 2005a, b). However, the effect of heterosis on related aspects of the visual characteristics of beef cattle seems to be not so significant. Menezes et al. (2005b) found that meat from steers have demonstrated $50 \%$ more marbling than the defined Charolais and $28.88 \%$ than the Nellore defined, but when these comparisons were performed for texture and coloration they were not significant.
The crossing of genotypes of continental or british origin improved meat tenderness of zebu cows when the evaluation was performed by evaluators (6.51, 6.19 points) (Table IV). The meat of the british crossbred was also superior to the continental defined (5.81 points). In other comparisons between genotypes there were no differences.

In the tender evaluation by Shear, it is observed that the meat of the continental crossbred cows $\left(4.22 \mathrm{kgf} / \mathrm{cm}^{3}\right)$ have demonstrated better values for tenderness of the meat cows the other genetic groups. In comparisons between meat

TABLE IV

Organoleptic characteristics of meat from cull cows of different genotypes.

\begin{tabular}{|c|c|c|c|c|}
\hline Genetic Group & Tenderness $^{1}$ & Shear, kgf/cm & Succulence $^{1}$ & Palatability \\
\hline Zebu & $5.20 \pm 0.46 c$ & $6.15 \pm 1.02 \mathrm{a}$ & $5.19 \pm 0.45$ & $6.29 \pm 0.43$ \\
\hline Continental & $5.81 \pm 0.17 b c$ & $5.56 \pm 0.35 a$ & $6.07 \pm 0.18$ & $6.20 \pm 0.15$ \\
\hline Zeb. and Brit. & $6.51 \pm 0.29 \mathrm{a}$ & $5.52 \pm 1.04 \mathrm{a}$ & $6.41 \pm 0.29$ & $6.62 \pm 0.27$ \\
\hline Zeb. and Cont. & $6.19 \pm 0.14 \mathrm{ab}$ & $4.22 \pm 0.28 b$ & $6.18 \pm 0.14$ & $6.57 \pm 0.13$ \\
\hline Medium & 6.10 & 5.09 & 6.29 & 6.47 \\
\hline Probability & 0.0336 & 0.0091 & 0.1482 & 0.2029 \\
\hline \multicolumn{5}{|l|}{ Diference } \\
\hline Definided $v c$ Crossbed & $0.56^{* *}$ & $-1.05 * *$ & 0.24 & 0.14 \\
\hline Cros. + Zeb. vs Cont. & 0.14 & -0.17 & -0.23 & 0.48 \\
\hline Cros. + Cont. vs Zeb. & 0.97 & -1.92 & 0.71 & -0.21 \\
\hline
\end{tabular}

$* \mathrm{P}<0.05 * * \mathrm{P}<0.10$; for the contrast analysis.

Cros. $=$ Crossbed; Zeb. $=$ Zebu; Cont. $=$ Continental.

${ }^{1}$ Scale 1 - 9 points, with $1=$ extremely chewy, tenderness and tasteless; $9=$ extremely tender, extremely tender and extremely tasty.

from cows or crossbred defined genotypes, it is observed that the heterotic effect of crossbreeding improved by 0.56 points (contrast analysis) on meat tenderness of cows by the taste panel and reduced by $1.05 \mathrm{kgf} / \mathrm{cm}^{3}$ shear force by Shear, demonstrating that the crossing can be an important tool for improvement of this variable in animals predominance of zebu.

Everybody knows that meat from zebu cattle in comparison to animals of European origin are constitutes become less tender (Crouse et al. 1989, Lage et al. 2012, Tizioto et al. 2014.). The main reason for this quality is the enzyme calpain activity regarding calpain in postmortem, which reduces the process of proteolysis of myofibrillar and undertakes the process of tenderness of the beef (Lage et al. 2009). Current research have evidenced that the nucleotide polymorphism in specific genes (KCNJ11) are related to meat tenderness of Nelore (Tizioto et al. 2014) animals. The authors suggest that identification of individuals with a higher propensity for the activity of these genes could help breeding programs breed. It should be emphasized that the meat of zebu females in this study had scores that determine them to be less soft, both when measured by the evaluation panel (5.20; points) and by Shear 
(6.15; kgf / cm) however, these differences were not enough to differ statistically from crossbred british and continental defined by Shear.

Even if the succulence has demonstrated a positive correlation with the tenderness panel $(r=0.64$, $\mathrm{P}=0.0002)$ and negatively with Shear $(r=-0.89$, $\mathrm{P}<0.0001$ ), it did not differ statistically between the genotypes. The same tenderness was observed for the palatability which, correlated with the tenderness, the panel $(\mathrm{r}=0.61, \mathrm{P}=0.0004)$ and Shear $(r=-0.70, p<0.0001)$; showing no significant differences. Oury et al. (2009) observed that the succulence and palatability attributes were linked with the (2009) lipid content in beef of Chalorais heifers. In the this study, marbling was not correlated with succulence $(\mathrm{r}=-0.24, \mathrm{P}=0.2065)$ and taste $(\mathrm{r}=-0.08, \mathrm{P}=0.6827)$. Pacheco et al. (2005) demonstrate that if liquid losses by thawing and cooking are high, the values of tenderness in meat from steers are smaller.
In a current rewiew, the effect of food on the characteristics of the meat (Patten et al. 2008, Vastergaard et al. 2000, 2007, Weber et al. 2013) hadn't significant influence of the termination systems of cattle (Table V). Even with differences in the time of termination of cows, 79 and 92 days; respectively for the feedlot and pasture, it was not enough to promote changes in most qualitative aspects of meat covered in this study. Vastergaard et al. $(2000,2007)$ has found that the time of termination has great influence on carcass characteristics and meat cows. These authors have pointed that attributes such as tenderness and color are improved as the time of termination of the animals are increased. In other hand, it is essential to strike a balance between improving the quality characteristics of beef cows and economic return of the production system, due to the increase in the time of termination leads to higher production costs and lower profitability of the system.

TABLE V

Qualitative characteristics of meat

from cull cows in feedlot or pasture termination system.

\begin{tabular}{ccccc}
\hline \multirow{2}{*}{ Variable } & \multicolumn{3}{c}{ System } & \multirow{2}{*}{ P } \\
\cline { 2 - 3 } & Confinement & Pasture & Average & \\
\hline Termination time & $78.53 \pm 4.69$ & $91.53 \pm 6.49$ & 83.09 & 0.0451 \\
${ }^{1}$ Coloration, points & $3.70 \pm 0.11$ & $3.54 \pm 0.14$ & 3.59 & 0.3012 \\
${ }^{2}$ Texture, points & $3.46 \pm 0.25$ & $3.20 \pm 0.32$ & 3.34 & 0.3348 \\
${ }^{3}$ Marbling, points & $7.20 \pm 0.55$ & $4.93 \pm 0.70$ & 5.98 & 0.0016 \\
${ }^{4}$ Tenderness, points & $6.07 \pm 0.16$ & $5.78 \pm 0.18$ & 6.10 & 0.7933 \\
Shear, kgf/cm & $6.22 \pm 0.41$ & $5.51 \pm 0.42$ & 5.09 & 0.0804 \\
${ }^{4}$ Succulence, points & $5.84 \pm 0.16$ & $6.09 \pm 0.17$ & 6.29 & 0.2091 \\
${ }^{4}$ Palatabillity, points & $6.44 \pm 0.15$ & $6.40 \pm 0.16$ & 6.47 & 0.7933 \\
\hline
\end{tabular}

${ }^{1}$ Coloration: 1 = dark; $2=$ dark red; $3=$ slightly dark red; $4=$ red; $5=$ bright red.

${ }^{2}$ Texture: 1 = very chewy; $2=$ chewy; $3=$ slightly chewy; $4=$ thin; $5=$ very thin.

${ }^{3}$ Marbling: $1-3=$ traits; $4-6=$ light; $7-9=$ small; $10-12=$ medium; $13-15=$ moderate; $16-18=$ abundant.

${ }^{4}$ Scale 1 - 9 points, with $1=$ extremely chewy, without tenderness and taste; $9=$ extremely tender, extremely tender and extremely tasty.

The coloration and texture were not affected by the termination system. Coloration oscillated from "slightly dark red" and "red" as the texture "slightly coarse." Berg and Butterfield (1976) suggest that confined animals, being less subjected to exercise, have meat color with lighter because of lower concentration of myoglobin in the muscle. Realini et al. (2004) suggest that further 
modulation of oxidative muscle fibers occurs in the muscle of fed cows on pasture, and according to that the meat of these becomes darker than animals in feedlot termination. Weber et al. (2013) attribute changes in color of beef under different feeding strategies modulation of muscle fibers, however, the authors point out that other factors also influence this variable.

The marbling was the only variable to suffer the effect of the production system, the cows in feedlot had meat with the rating "small" (7.20 points), while the animals in termination pasture, "light" (4.93 points). Possibly the greatest physical effort of cows on termination pasture, due to shifts in search of food, contributed to that in feedlot demonstrated greater marbling, due to the intramuscular fat is the first to be oxidized in situations of increased demand energy, animals or situations of dietary restrictions (Di Marco 1998). Another possible explanation is precisely in the diets of cows, since the diets based on grains in feedlots can promote increased expression of intramuscular fat (marbling). According Pethwick et al. (2004) fat marbling is influenced by several factors, such as weight early termination, genetic propensity for marbling, body size at maturity, growth rate in growing and growth pattern, however, for these authors the grain based diets high energy as corn, often used as a base in the composition of the concentrate in feedlot diets evaluated in studies may explain the higher expression of fat marbling in cattle in feedlots.

The values for tenderness evaluated by Shear between production systems $(5.09 \mathrm{kgf} / \mathrm{cm})$, show that meat from cows demonstrated pattern of tenderness above reported as acceptable for tender meat, $<4.6 \mathrm{kgf} / \mathrm{cm}$ (Shackelford et al. 1991) or $<5 \mathrm{kgf} / \mathrm{cm}$ (Felício 1997), regardless of the finishing system. Another relevant point to be considered in relation is the numerical difference to the tenderness of the meat of cows in feedlot $\left(6.22 \mathrm{kgf} / \mathrm{cm}^{3}\right)$ compared to cows on termination pasture $\left(5.51 \mathrm{kgf} / \mathrm{cm}^{3}\right)$, although this difference not differed statistically $(\mathrm{P}=0.0804)$ is perceptible trend of better values for tenderness of the meat finished on pasture. Various researches demonstrate that termination of feedlot steers improve meat tenderness (Vaz et al. 2007 and Menezes et al. 2010). Weber et al. (2013) observed that an increase in energy intake in the diet of cows promoted improvements in the tenderness of the meat, which was attributed by the authors to increased solubility of collagen. Other studies have shown that variations in the energy density of the diet could modify the tenderness as a function of the modulation of muscle fibers (Patten et al. 2008, Sawyer et al. 2004). Possibly the trend observed in this study may be associated with differences in the time of termination of cows in feedlot or pasture, so that those subject to termination for a period of longer (pasture) had higher solubility of collagen and therefore improvements in meat tenderness.

The termination of the cows in confinement or pasture did not affect the succulence and taste of the meat. Although some researches show differences between finishing systems for beef palatability in cattle (Vaz et al. 2007, Menezes et al. 2010), this trend was not significant in this study. The palatability appears to be sensitive to dietary characteristic, which affects the amino acid profile, level and type of fat stored in the muscle (Lawrie 2005).

The age class affected the qualitative aspects of beef (Table VI). The color of the meat of females classified as young (3.43 points), adult (3.55 points) and old (3.88 points) showed no difference, being classified as "slightly dark red". By contrast analysis, it is observed that the slaughter of cows aged 8 (youth and adult), caused a significant reduction of 0.43 points in color, indicating that the reduction of the age at slaughter cull cows can lead to higher browning of the meat, these results, which do not corroborate those observed in the literature in relation to this variable. Berg and Butterfield (1976) explain that the coloration is an aspect 
which is sensitive to age and physical activity because promote higher levels of myoglobin in muscle, which gives darker coloration to the meat with advancing age and increasing physical activity. However, Gatellier et al. (2005) found that the concentration of myoglobin in cows under 12 years of age is not changed, the authors suggest that the concentration of myoglobin increases rapidly to 24 months of age, after this period other aspects can affect this variable. The coloration correlated with succulence $(\mathrm{r}=-0.51, \mathrm{P}=0.0044)$ and taste $(r=-0.64, P=0.0001)$, is an important variable for estimating sensory aspects of meat and that can be perceived by the consumer at the retail level.

TABLE VI

Qualitative characteristics of meat from cull cows of different age classes of slaughter.

\begin{tabular}{cccc}
\hline Age classes & Coloration $^{\mathbf{1}}$ & Texture $^{2}$ & Marbling $^{\mathbf{3}}$ \\
\hline Young & $3.43 \pm 0.18$ & $4.09 \pm 0.40^{\mathrm{a}}$ & $4.96 \pm 0.94$ \\
Adult & $3.55 \pm 0.14$ & $2.76 \pm 0.32^{\mathrm{b}}$ & $6.64 \pm 0.71$ \\
Old & $3.88 \pm 0.15$ & $3.14 \pm 0.34^{\mathrm{ab}}$ & $6.60 \pm 0.77$ \\
Medium & 3.59 & 3.34 & 5.98 \\
\cline { 2 - 4 } Probability & 0.3107 & 0.0487 & 0.5989 \\
\cline { 2 - 4 } Diference & & & \\
Young. $v$ s Adults. + Old. & -0.23 & 0.37 & -1.01 \\
Old. $v s$ Young + Adult. & $-0.42^{*}$ & 0.13 & 1.03 \\
\hline
\end{tabular}

$* \mathrm{P}<0.05$ for contrast analysis.

${ }^{1}$ Color: $1=$ dark; 2 =dark red; $3=$ slightly dark red; $4=$ red; $5=$ bright red.

${ }^{2}$ Texture: 1 = very chewy; $2=$ chewy; $3=$ slightly chewy; $4=$ thin; $5=$ very thin.

${ }^{3}$ Marbling: $1-3=$ traits; $4-6=$ light; $7-9=$ small; $10-12=$ medium; $13-15=$ moderate; 16 - 18 = abundant.

TABLE VII

Organoleptic characteristics of meat from cull cows of different age classes.

\begin{tabular}{ccccc}
\hline Genetic Group & Tenderness $^{\mathbf{1}}$ & ${\text { Shear, } \mathbf{~ k g f} / \mathbf{c m}^{3}}^{\mathbf{2}}$ & Succulence $^{\mathbf{1}}$ & Palatability $^{\mathbf{1}}$ \\
\hline Young & $6.17 \pm 0.50$ & $4.80 \pm 0.99$ & $4.70 \pm 0.52 \mathrm{~b}$ & $6.52 \pm 0.46$ \\
Adult & $5.92 \pm 0.18$ & $6.08 \pm 0.44$ & $6.47 \pm 0.19 \mathrm{a}$ & $6.61 \pm 0.17$ \\
Old & $5.69 \pm 0.35$ & $6.71 \pm 0.73$ & $6.72 \pm 0.36 \mathrm{a}$ & $6.12 \pm 0.32$ \\
\cline { 2 - 5 } Medium & 6.10 & 5.09 & 6.29 & 6.47 \\
\cline { 2 - 5 } Probability & 0.1335 & 0.4740 & 0.0181 & 0.1335 \\
\cline { 2 - 5 } Diference & & & -0.42 & -0.25 \\
Young. vs Adult. + Old. & 0.39 & 0.53 & -0.04 & -0.10 \\
Old. $v$ Young + Adult. & $-0.33^{* *}$ & -0.14 & &
\end{tabular}

$* * \mathrm{P}<0.10$; for the analysis of contrast.

${ }^{1}$ Scale 1 - 9 points, with $1=$ extremely chewy, without succulence and tasteless; $9=$ extremely tender, extremely juicy and extremely tasty.

The texture of the meat younger cow (4.09 points) were classified as "thin", while adult (2.76 points) and old (3.14 points) of "chewy" and "slightly rough", respectively. However, there was statistical difference only between the meat of the young relate to adult animals. This difference was expected, since the advancing age of slaughter of animals the diameter of muscle fibers increase. It will generate chewier texture meat in old animals in comparison to cattle at younger age (Muller 1987). 
Although the marbling in meat from young females (4.96 points) was numerically lower than that of adults (6.64 points) and old (6.60 points), these differences were not significant.

The age class of the cows did not affect the organoleptic characteristics of meat (Table VII). The tenderness, although it has shown a tendency to be softer in cows classified as young adult relative or old females, these differences were not significant. Although cows older age may demonstrate with meat better tenderness than younger cows, due to common compensatory gains in old animals (Andersen et al. 2005.) and increased solubility of collagen, as suggested by some authors (Vaz et al. 2007, Weber et al. 2013), this behavior was not observed in the meat of females classified as old, but, when those evaluated by contrast analysis have demonstrate a reduction in score of softness by the evaluation panel, in order to 0.33 points, with no differences by Shear. The similarity in this variable between the categories of cows classified in the current study, taking a comprehensive view of the production system, justifies the use of arrays as much as possible for reproduction instead of killing them with younger age, when the objective is to produce good quality meats, since the reduction of slaughter age of this category may not reflect in significant improvements in quality of meat.

The juiciness of the cows was influenced by age class of cows $(\mathrm{P}=0.0181)$. The meat of cows classified as youth showed lower juiciness (4.70; points) than meat from cows classified as adults (6.47; points) and old (6.72; points), the latter being similar. Since the texture of the meat was not affected by age class of cows $(P=0.1335)$. Some studies suggest that the succulence and taste are influenced by marbling of meat (Lawrie 2005, Vaz et al. 2007). However, they do not present correlation with the latter variable. Beyond these variables correlate with the coloring of the meat, as previously discussed, they are also linked with tenderness, as assessed by the panel $(\mathrm{r}=0.64, \mathrm{P}=$
$0.61 \mathrm{r}=0.0002, \mathrm{P}=0.0004$, respectively) and shear $(\mathrm{r}=-0.89, \mathrm{p}<0.0001$, and $\mathrm{r}=-0.70, \mathrm{p}<0.0001$, respectively). These results agree with Galli et al. (2008), who also do not found differences for the effect of age at slaughter of cull cows on the succulence of the meat. But, for these authors, the meat of culled cows no matter the age class, can be regarded as acceptable in qualitative terms.

\section{CONCLUSION}

The genotype of cull cows affects the qualitative and organoleptic characteristics of meat. In general, the intersection of European breeds with Zebu improves the quality of meat, in relation to races defined as Zebu.

The use of containment can improve the marbling of beef cows. However, other qualitative and organoleptic characteristics of meat are not affected by finishing system, which can be considered beneficial to the termination systems of that category on pasture, common in Brazil.

Although the reduction in age at slaughter cows turn better the visual and tactile aspects of the meat, it does not promote improvements in organoleptic aspects capable of being perceivable by the consumer. It makes the strategy of reducing the age of slaughter of cows in order to improve meat quality are not possible in the production system and genotypes used in the country.

\section{RESUMO}

O objetivo deste estudo foi avaliar, por meio de metaanálise, a qualidade da carne de vacas de acordo com o genótipo, sistema de terminação e classe de idade ao abate. A partir de uma pesquisa na internet, foram identificados 15 artigos com informações relacionadas à qualidade da carne de vacas para abate. Os dados foram agrupados conforme o genótipo das vacas, sendo eles: definidos zebuínos ou continentais, cruzados zebuínos $\mathrm{x}$ britânicos ou zebuínos $\mathrm{x}$ continentais; conforme o sistema de terminação: confinamento ou pastagem; em relação à idade de abate, sendo ela: até 4 anos 
(jovem), de 4 a 8 anos (adulta) ou mais de 8 anos de idade (velha). A carne das vacas mestiças continentais foi mais macia que a dos demais genótipos, seja através do painel de avaliadores ou pelo Shear. A carne de vacas terminadas em confinamento demonstrou maior grau de marmorização em relação à carne das fêmeas terminadas em pastagem. A redução da idade de abate das vacas melhorou a coloração da carne. O genótipo das vacas afeta os aspectos organolépticos da carne enquanto o sistema de terminação e idade de abate afetam os aspectos sensoriais da carne.

Palavras-chave: confinamento, fêmeas bovinas, maciez, mestiças, shear, zebuína.

\section{REFERENCES}

ANDERSON DB, Moody DE AND HANCOCK DL. 2005. Beta adrenergic agonist. In: Bell WGPAW (Ed), Encyclopedia of Animal Science. Reino Unido: Taylor e Francis, p. 104107.

BERG RT AND BUTTERFIELD RM. 1976. New concepts of cattle growth. Sydney: Sydney University Press, 240 p.

Cattelam J, Menezes LFG, Ferreira JJ, Restle J, Arboitte MZ AND PAULA PC. 2009. Composição física da carcaça e qualidade da carne de novilhos e vacas de descarte de diferentes grupos genéticos submetidos a diferentes frequências de fornecimento de alimentação. Ci Anim Bras 10(3): 764-775.

Crouse JD, Cundiff LV, Koch RM, Koohmaraie M And SEIDEMAN SC. 1989. Comparisons of Bos indicus and Bos taurus inheritance for carcass beef characteristics and meat palatability. J Anim Sci 67(10): 2661-2668.

Di MARCO ON. 1998. Crecimiento de vacunos para carne. $1^{\circ}$ ed., Mar Del Plata: ON Di Marco, 246 p.

FELÍCIO PE. 1997. Fatores ante e postmortem que influenciam na qualidade da carne bovina. In: Peixoto AM, Moura JC and Faria VP. Produção do novilho de corte. Piracicaba: FEALQ, p. 79-97.

FERNANDES ARM, SAMPAIO AAM, HENRIQUE W, OLIVEIRA EA, TUllio RR AND PERECIN D. 2008. Características da carcaça e da carne de bovinos sob diferentes dietas, em confinamento. Arq Bras Med Zootec 60(1): 139-147.

FIELD RA. 1971. Effect of castration on meat quality and quantity. J Anim Sci 32(5): 849-858.

Galli I, Teira G, Perlo F, Bonato P, Tisocco O, Monje A AND VitTone S. 2008. Animal performance and meat quality in cull cows with early weaned calves in Argentina. Meat Sci 79: 521-528.

GATEllier P, Mercier I, Juin H AND RenerRe M. 2005. Effect of finishing mode (pasture or mixed-diet) on lipid composition, colour stability and lipid oxidation in meat from Charolais cattle. Meat Sci 69: 175-186.
Jurie C, Martin JF, Listrat A, JaILler R, Culioli J AND PICARD B. 2006. Carcass and muscle characteristics of beef cull cows between 4 and 9 years of age. Anim Sci 82: 415-421.

Kuss F, Restle J, Brondani IL, Alves Filho DC, PEROTTONI J, Missio RL AND AMARAL GA. 2005. Composição física da carcaça e qualidade da carne de vacas de descarte de diferentes grupos genéticos terminados em confinamento com distintos pesos. R Bras Zootec 34(4): 1285-1296.

Kuss F, Restle J, Deschamps F, Kosloski GV, Santos AP, Menezes LFG AND Fiamoncini J. 2006. Perfil de ácidos graxos e qualidade da carne de vacas de descarte terminadas em confinamento recebendo dietas de com ou sem adição de monensina. Cienc Rural 36(5): 1518-1521.

Lage JF, Oliveira IM AND PAUlino PVR. 2009. Papel do sistema calpaina calpastatina sobre a proteólise muscular e sua relação com a maciez da carne em bovinos de corte. R Elect Vet 10(12): 770-774.

LAgE JF, PAUlino PVR, VAladares Filho SC, SOUZA EJO, DUARTE MS, BENEDETI PDB, SOUZA NKP AND COX RB. 2012. Influence of genetic type and level of concentrate in the finishing diet on carcass and meat quality traits in beef heifers. Meat Sci 90: 770-774.

LAWRIE RA. 2005. Ciência da carne. $6^{\text {a }}$ ed., Porto Alegre: Artmed, $384 \mathrm{p}$.

LeÃo JP, Neiva JNM, Restle J, Missio RL, Paulino PVR, MiotTo FRC, SANTANA AEM, SOUZA LF AND ALEXANDRINO E. 2013. Carcass and meat characteristics of different cattle categories fed diets containing crude glycerin. Semi 34(1): 431-444.

Marques Ja, Prado In, Molleta JL, Prado IM, Prado JM, MACEDO LMA, SOUZA NE AND MATSUSHITA M. 2006. Características físico-químicas da carcaça e da carne de novilhas submetidas a anestro cirúrgico ou mecânico terminadas em confinamento. R Bras Zootec 35(4): 1514-1522.

Menezes LFG, Restle J, Brondani IL, Alves Filho DC, Kuss F, Silveira MF AND Amaral GA. 2005a. Características da carcaça de novilhos de gerações avançadas do cruzamento alternado entre as raças Charolês e Nelore, terminados em confinamento. R Bras Zootec 34(3): 934-945.

Menezes LFG, Restle J, Brondani IL, Silveira MF, FreitAs LS AND PIZZUTI LAD. 2010. Características da carcaça e da carne de novilhos superjovens da raça Devon terminados em diferentes sistemas de alimentação. R Bras Zootec 39(3): 667-676.

Menezes LFG, Restle J, VAZ FN, Brondani IL, Alves Filho DC, FREITAS AK AND METZ PAM. 2005b. Composição física da carcaça e qualidade da carne de novilhos de gerações avançadas do cruzamento alternado entre as raças charolês e nelore, terminados em confinamento. R Bras Zootec 34(3): 946-956.

Menezes LFG, Segabinazzi LR, Brondani IL, Restle J, ARBOITTE MZ, KUSS F, PACHECO OS AND ROSA JRP. 2009. Silagem de milho e grão de sorgo como suplementos para vacas de descarte terminadas em pastagem cultivada de estação fria. Arq Bras Med Zootec 61(1): 182-189. 
Metz PAM, Menezes LFG, Arboitte MZ, Brondani IL, RESTLE J AND CALLEGARO A. 2009. Influência do peso ao início da terminação sobre as características de carcaça e da carne de novilhos mestiços Nelore $\times$ Charolês. R Bras Zootec 38(2): 346-353.

Moura ICF, Kuss F, Molleta JL, Perotto D, Strack MG AND MENEZEs LFG. 2013. Terminação em confinamento de vacas de descarte recebendo dietas com diferentes de concentrado. Semin Cienc Agrar 34(1): 399-408.

Muller L. 1987. Normas para avaliação de carcaças e concurso de carcaça de novilhos. $2^{\text {a }}$ ed., Santa Maria: Universidade Federal de Santa Maria, 31 p.

Osmari MP, ARboitTe MZ, Brondani IL, Kuss F, Alves FILHO DC AND RESTLE J. 2008. Vacas terminadas em campo nativo suplementadas com farelo de trigo ou farelo de arroz integral contendo ou não monensina sódica. Ciênc Agrotec 32(6): 1974-1980.

OURY MP, PICARD B, BRIAND M, BLANQUET JP AND DUMONT R. 2009. Interrelationships between meat quality traits, texture measurements and physicochemical characteristics of M. rectus abdominis from Charolais heifers. Meat Sci 83: 293-301.

Pacheco PS, Restle J, Silva JHS, Brondani IL, Pascoal LL, Alves Filho DC, ARboitte MZ and Freitas AK. 2005. Composição física da carcaça e qualidade da carne de novilhos jovens e superjovens de diferentes grupos genéticos. R Bras Zootec 34(5): 1691-1703.

PATten LE, Hodgen JM, Stelzleni AM, CALKins CR, JOHNSON DD AND GWARTNEY BL. 2008. Chemical properties of cow and beef muscles: Benchmarking the differences and similarities. J Anim Sci 86: 1904-1916.

Pethick DW, HARPER GS AND ODDY VH. 2004. Growth, development and nutritional manipulation of marbling in cattle: a review. Aust J Exp Agr 44(7): 705-715.

REALINICE, DUCKETT SK, BRITO GW, DALLA RizZAMANDDE MATTOS D. 2004. Effect of pasture vs. concentrate feeding with or without antioxidants on carcass characteristics, fatty acid composition, and quality of Uruguayan beef. Meat Sci 66: 567-577.

Restle J, Cerdótes L, VAz FN and Brondani I. 2001a. Características da carcaça e da carne de novilhas charolês e 3/4 charolês 1/4 Nelore, terminadas em confinamento. R Bras Zootec 30(3): 1065-1075.

Restle J, VAZ FN, Bernardes RAC, PAscoal LL, Menezes LFG AND PACHECO PS. 2003. Características de carcaça e da carne de vacas de descarte de diferentes genótipos charolês $\mathrm{x}$ nelore, terminadas em confinamento. Cienc Rural 33(2): 345-350.

Restle J, Vaz FN, Roso C, Oliveira NA, Cerdótes L AND MENEZES LFG. 2001b. Desempenho e características da carcaça de vacas de diferentes grupos genéticos em pastagem cultivada com suplementação energética. R Bras Zootec 30(6): 1813-1823.

SAWYER JE, MATHIS CP AND DAVIS B. 2004. Effects of feeding strategy and age on live animal performance, carcass characteristics, and economics of short-term feeding programs for culled beef cows. J Anim Sci 82: 3646-3653.
Shackelford SD, Koohmaraie M, Miller MF, Crouse JD AND REAGAN JO. 1991. An evaluation of tenderness of the longissimus muscle of Angus by Hereford versus Brahman crossbred heifers. J Anim Sci 69(1): 171-177.

Stelzleni AM, Patten LE, Johnson DD, CALKIns CR AND GWARTNEY BL. 2007. Benchmarking carcass characteristics and muscles from commercially identified beef and dairy cull cow carcasses for Warner-Bratzler shear force and sensory attributes. J Anim Sci 85: 2631-2638.

St-PIERRE NR. 2007. Design and Analysis of Pen Studies in the Animal Sciences. J Dairy Sci 90(Suppl.): 87-99.

Tizioto PC ET AL. 2014. Calcium and potassium content in beef: Influences on tenderness and associations with molecular markers in Nellore cattle. Meat Sci 96: 436-440.

VAstergaArd M, MAdSEn NT, BligaArd HB, Bredahl L, RASMUSSEN PT AND ANDERSEN HR. 2007. Consequences of two or four months of finishing feeding of culled dry dairy cows on carcass characteristics and technological and sensory meat quality. Meat Sci 76: 635-643.

VASTERGAARD M, THERKILDSEN M, HENCKEL P, JENSEN LR, ANDERSEN HR AND SEJRSEN K. 2000. Influence of feeding intensity, grazing and finishing feeding on meat and eating quality of young bulls and the relationship between muscle fibre characteristics, fibre fragmentation. Meat Sci 54:187-195.

Vaz FN, Restle J, ARboitte MZ, Pascoal LL, Alves Filho DC AND PACHECO RF. 2010. Características da carcaça e da carne de novilhos e novilhas superjovens, terminados com suplementação em pastagem cultivada. Ci Anim Bras 11(1): 42-52.

VAZ FN, REstle J, BRondANI IL, COSTA EC, VAZ RZ, Roso C AND CARRILHO CO. 2002a. Suplementação energética sobre a qualidade da carcaça e da carne de vacas de diferentes idades, terminadas em pastagem cultivada de estação fria sob pastejo horário. R Bras Zootec 31(1): 173-182.

Vaz FN, Restle J, PAduA JT, Metz PAM, Moletta JL AND FERNANDES JJR. 2007. Qualidade da carcaça e da carne de novilhos abatidos com pesos similares, terminados em diferentes sistemas de alimentação. Ci Anim Bras 8(1): 31-40.

VAZ FN, RESTle J, QuAdros ARB, PASCOAL LL, SAnches LMB, Rosa JRP AND MENEZES LFG. 2002b. Características da carcaça e da carne de novilhos e de vacas de descarte hereford, terminadas em confinamento. R Bras Zootec 31(3): 1501-1510.

VeISETHE, SHACKELFORdSD, WheELER TLAND KoOHMARAIE M. 2004. Factors regulating lamb Longissimus tenderness are affected by age at slaughter. Meat Sci 68: 635-640.

Weber MJ, Dikeman ME, JAEger JR, UnRUh JA, Murray L AND HOUSE TA. 2013. Effects of feeding a single or sequence of beta-adrenergic agonists on cull cow meat quality. Meat Sci 93: 275-281 
